\title{
Environmental Prevalence of Carbapenem Resistance Enterobacteriaceae (CRE) in a Tropical Ecosystem in India: Human Health Perspectives and Future Directives
}

\author{
Periyasamy Sivalingam ${ }^{1,2, *}$, John Poté $^{1}$ and Kandasamy Prabakar ${ }^{3, *}$ \\ 1 Department F.-A. Forel for Environmental and Aquatic Sciences and Institute of Environmental Sciences, \\ School of Earth and Environmental Sciences, Faculty of Science, University of Geneva, Uni Carl Vogt, \\ 66 Boulevard Carl-Vogt, CH-1211 Geneva 4, Switzerland; John.pote@unige.ch \\ 2 Postgraduate and Research Department of Microbiology, Jamal Mohamed College, Tiruchirappalli 620020, \\ Tamil Nadu, India \\ 3 Postgraduate and Research Department of Zoology, Jamal Mohamed College, Tiruchirappalli 620020, \\ Tamil Nadu, India \\ * Correspondence: Sivalingam.periyasamy@unige.ch or biosivas@gmail.com (P.S.); drpklab@gmail.com (K.P.); \\ Tel.: +91-431-2331135 (K.P.); Fax: +91-431-2331435 (K.P.)
}

Received: 1 August 2019; Accepted: 29 September 2019; Published: 2 October 2019

check for updates

\begin{abstract}
In the past few decades, infectious diseases have become increasingly challenging to treat, which is explained by the growing number of antibiotic-resistant bacteria. Notably, carbapenemresistant Enterobacteriaceae (CRE) infections at global level attribute a vast, dangerous clinical threat. In most cases, there are enormous difficulties for CRE infection except a few last resort toxic drugs such as tigecycline and colistin (polymyxin E). Due to this, CRE has now been categorized as one among the three most dangerous multidrug resistance (MDR) pathogens by the US Centres for Disease Control and Prevention (CDC). Considering this, the study of the frequency of CRE infections and the characterization of CRE is an important area of research in clinical settings. However, MDR bacteria are not only present in hospitals but are spreading more and more into the environment, thereby increasing the risk of infection with resistant bacteria outside the hospital. In this context, developing countries are a global concern where environmental regulations are often insufficient. It seems likely that overcrowding, poor sanitation, socioeconomic status, and limited infrastructures contribute to the rapid spread of MDR bacteria, becoming their reservoirs in the environment. Thus, in this review, we present the occurrence of CRE and their resistance determinants in different environmental compartments in India.
\end{abstract}

Keywords: antibiotic resistance bacteria; CRE; environment; India

\section{Introduction}

By 2050, drug-resistant infections have been estimated to cause global economic burden and claim more mortality than cancer [1], which indicate the apparent caution. The excessive use of antibiotics in human healthcare and agriculture selects for resistance and is, therefore, the leading cause of the spreading antibiotic resistance bacteria (ARB). Of the world's consumption, India is the leading consumer of antibiotics [2]. According to the national public health foundation, India has the highest level of infectious disease in the world and thus the consequences of antibacterial resistance could be devastating [3]. However, there is a lack of healthcare spending and is far less when compared to the per capita [3,4]. Furthermore, the World Health Organization (WHO), and India's National Action 
Plan recently recognized the mitigation of antibiotic resistance in the environment as a pillar for a practical "One-health" approach to the problem $[5,6]$.

The introduction of antibiotic compounds into the aquatic environment resulted in selective pressure on resident bacteria [7]. For example, some antibiotics could also be found in groundwater, deeper than $10 \mathrm{~m}$ [8]. It has been noted that the presence of antibiotics, even at low concentrations below the minimal inhibitory concentration (MIC), has been reported to promote various cell responses to the stress, e.g., growth arrest or cell death [9]. Besides, they can also promote horizontal gene transfer (HGT) among the microorganisms [10] and select for ARB [11]. Antibiotic resistance genes (ARGs) are frequently carried on mobile genetic elements, meaning that they can be easily transferred from one bacterium to the other. It has been reported that ARGs acquired by microorganisms could be transferred among microbes from one ecosystem to others [12]. The presence of diverse collections of resistance genes in environmental microbial communities suggests that they could be mobilized into pathogenic bacteria [13-15].

The effluent treatment process could be one of the major routes in the dissemination of ARB into the environment [16]. Indeed, studies have demonstrated that the microbial community in an unpolluted soil site harbours unique and ancient $\beta$-lactam resistance determinants [17,18]. Antibiotic-free (Virgin) environments are known to have several antibiotic resistance genes as housekeeping genes, and some of them share a close similarity with genes present in pathogenic microbiota $[12,19,20]$. Aminov (2009) also reported that the evolutionary and ecological perspective revealed that antibiotics have evolved as another way of intra- and inter-domain communication in various ecosystems [19]. Although antibiotics and resistant genes had been widely distributed in the environment before the introduction of antibiotics in clinical practice, human-driven changes have probably increased the prevalence of ARB in the water [21].

Ram et al. (2007) demonstrated that industrial effluents, hazardous chemicals from non-point sources of agriculture and health sectors, and inadequate cremation procedures along the banks have a serious impact on physicochemical and microbiological water quality of the river in India [22]. Consequently, the sediments, as well as the surface water, were found to have significant sources of organic carbon, phosphorus, and nitrogen. It is noteworthy that soil composition and the presence of heavy metals might enrich the antibiotic resistance genes in natural ecosystems [23,24]. Manure and sludge applied to the agricultural fields are also known to contaminate the soil and surface of food crops [25-27]. The soil has been reported as the largest reservoir of ARGs and is largely unstudied [28]. Soil may also act as a potential source to emerge in clinically important bacteria [29]. Hence, the understanding of the distribution and function of ARGs in soils and sediments will provide valuable information about their role in natural environments [30]. Many studies proposed that bacteria of faecal origin can be used as pollution indicators in the aquatic habitat and might be associated with the spread of infectious disease [31,32]. Besides, it may also be used to assess the clinical resistance associated with the regional level in the aquatic habitat $[33,34]$.

It has been documented that water is one of the most important habitats on Earth and serves as a significant reservoir of antibiotic resistance [35,36]. It has also been reported that water is the primary receptor and serves as a path to disseminate bacteria from human and animal origin [37]. An impressive number of studies have demonstrated that treated and untreated urban, and hospital effluents, wastewater treatment plants (WWTP), and rainfall play an essential role in the spread of antibiotic resistance in the aquatic environment [38-43].

As evidenced above, the environmental compartments appear to act as a reservoir of antibiotic resistance [44]. Among the ARBs, the emergence and spread of carbapenem-resistant Enterobacteriaceae (CRE) is a potential public health risk worldwide. Though several advancements have been made to survey CRE in clinical settings, still only a very few studies have been reported from the environmental compartments worldwide. For instances, urban river ecosystem in Spain is known to have CRE with Klebsiella pneumoniae carbapenemase (KPC), Verona integron-encoded metallo- $\beta$-lactamase (VIM-1), and imipenemase (IMI-2) [45]. KPC-producing Enterobacteriaceae have been reported from water sampled from rivers in Portugal [46]. In Switzerland, one river was found to be positive for the 
presence of carbapenemase-producing $\left(\right.$ bla $\left.a_{\mathrm{VIM}}\right)$ Klebsiella pneumoniae subsp. pneumoniae [47]. The river Danbue has also been reported to have Enterobacteriaceae harbouring New Delhi metallo- $\beta$-lactamases (NDM-1) and KPC-2 [48]. More recently, in South Korea, an urban river water sample was identified to have Klebsiella variicola harbouring NDM-9 [49].

Considering the spread of resistances in environmental compartments, it becomes important to study the distribution and frequency level of these bacteria in environments where infrastructure is often inadequate. In India, CRE was first identified in clinical settings [50], and have become increasingly reported to occur in environmental compartments which have now provoked a serious concern. This review provides insight into the regional distribution of CRE in various environmental compartments such as hospital effluents, surface water from rivers, lakes, surface sediments, and fish in India.

\section{Carbapenem Resistance Enterobacteriaceae}

Enterobacteriaceae are belonging to the family of Gram-negative bacilli that includes the genera of Escherichia, Klebsiella, Enterobacter, Serratia, Citrobacter, Proteus, and Morganella [51]. Gram-negative bacteria that produce $\beta$-lactamases can inactivate $\beta$-lactams antibiotics, rendering them useless [52]. Carbapenems, a group of broad-spectrum antibiotics, are $\beta$-lactams, including imipenem, meropenem, and ertapenem, which currently are used to treat multidrug-resistant Enterobacteriaceae [53,54]. Khan et al. 2017 reported that the general mechanisms of resistance in CRE are the expression of $\beta$-lactamases, efflux pumps, loss of OprD porin, and alteration in penicillin-binding proteins (PBPs) [55].

In recent years, carbapenem-resistant Enterobacteriaceae have gained utmost importance due to having one of the least possible options to treat the infections. Mollenkopf et al. 2017 reported that CRE is emerging as a critical healthcare-associated pathogen in developed/developing nations with high fatality rates [56]. It is evident that the genes encoding resistance to carbapenem are mostly located on plasmids and associated with insertion sequences, integrons, and transposons, which facilitate their further spread [57]. The primary causative reason associated with its rapid spread is the horizontal gene transfer (HGT) mechanism among the Enterobacteriaceae [52]. There have been three main classes of carbapenemases reported, including Ambler class A B-lactamases (KPC), class B (metallo-enzymes NDM, VIM), and class D carbapenem-hydrolysing oxacillinase (OXA-48 type) [58]. Metallo $\beta$-lactamase and Ambler class A, C, and D carbapenemases, have been differentiated based on the divalent cation and amino acid requirements for their enzymatic activity. The metallo $\beta$-lactamase does need divalent cation of $\mathrm{Zn}$ and serine for Ambler classes A, C, and D [59].

The global epidemiology and dissemination of CRE are mainly attributed to KPC, OXA-48, and $N D M$ genes [60]. Notably, the emerging antibacterial resistance in carbapenem-resistant gram-negative bacteria, such as $b l a_{\mathrm{NDM}}$, harbouring Enterobacteriaceae is one of the most challenging health concerns worldwide. Several reports emphasized that CRE harbouring an NDM gene isolated from hospitalized patients in the U.S., Sweden, and the UK were previously known to receive medical care in India [61-64]. Although the origin of $b l a_{\mathrm{NDM}}$ is still controversial, it is spreading rapidly across countries. However, researchers raise concern that peninsular India is one among several countries endemic to NDM. To support this, some of the locally acquired NDM infections have been reported in Canada [65], China [66], France [67], Guatemala [68], Israel [69], Oman [70], Kenya [71], Kuwait [72], South Africa [73], South Korea [74], Serbia [75], and Thailand [76]. Furthermore, it should be noted that India has been reported to have the highest rate of extended-spectrum $\beta$-lactamase (ESBL) producing bacteria [77].

\section{Global Clonal Type of CRE}

In clinical settings, earlier reports have been documented that the occurrence of KPC-producing K. pneumoniae in Italy, Europe, and the USA is predominantly in sequence type ST258 [78-80]. On the other hand, ST11 or ST147 accounts for over 50\% of NDM harbouring K. pneumoniae in India [81]. The endemic spread of OXA-48 associated with K. pneumoniae has been reported in India [82]. The sporadic spread was observed in K. pneumoniae harbouring OXA-48 in developed nations and mostly associated with clonal type ST101 [83,84]. Thus, the prevalence of CRE and its most dominant ST type has been well studied in clinical settings. However, there is a dearth of studies in environmental 
compartments. Rima Tafoukt et al. 2017 reported that different ST types among E. coli and K. pneumoniae isolated from river water in Algeria harbouring $b l a_{\mathrm{OXA}}-48$. They found six different sequence types (ST) in E. coli including ST559, ST38, ST212, ST3541, ST1972, and ST2142 and three different ST types in K. pneumoniae including ST133, ST2055, and ST2192 [85]. More importantly, K. pneumoniae harbouring KPC-2 associated with ST437 (CC11) isolated from the river Tiete^ and Pinheiros in Brazil [86]. In the time of globalization, the spread of ARB does not stop on one national border, as humans, animals, and food products travelling the world in a few hours are carrying their hosted CRE with them, indicating that CRE is not restricted to geographical locations [87-89].

\section{Surface Water and Sediments as Reservoir for CRE}

\subsection{Situation in India}

Pathogenic bacteria which can survive and spread in the environment are of significant human health concern. Schaefer et al. 2008 reported that contamination of water bodies by anthropogenic activities cause $80 \%$ of illness and mortality in developing countries [90]. Overwhelmingly, in India alone, $60 \%$ of people do not have adequate sanitation, including toilets and no proper wastewater treatment plants (WWTP) in most of the cities [91,92]. River and lake ecosystems have been of central value to most of the Indian population by providing drinking water supply. However, more worryingly in the recent past, an increase in the discharge of untreated/partially treated urban effluents, industrial effluents, open defecation, recreational activities, and agriculture wastewater running directly into several lakes and rivers has caused a significant decrease in water quality and has tremendous impacts (Figure 1). Of note, the availability of newer generation antibiotics in pharmacies in India-over the counter sale as well as without (valid) prescription-are frequent and in some cases, carbapenem too $[93,94]$. The combination of the poor sanitation and the massive misuse of antibiotics in India resulted in the rapid spread of the ARB.

ARB and ARGs found in environmental compartments are closely related to those found in clinical environments $[95,96]$. As a result, a recent study emphasized that the aquatic environment acts as a hot-spot for horizontal gene transfer [39]. The environmental contamination of CRE is sparsely studied both in developed and developing countries. Although the bla $a_{\mathrm{NDM}-1}$ gene has been first identified in clinical settings [50], it has also been found in environmental samples such as water, soil, and sediment. However, the lack of information on these environmental compartments prevents efficient identification of human health risks. Therefore, active surveillance for CRE would be of high importance in environmental compartments in India with varying anthropogenic pressure. Until now, geographically in India, a few studies addressing the environmental prevalence of CRE have been performed at the regional level and discussed below (Figure 2).
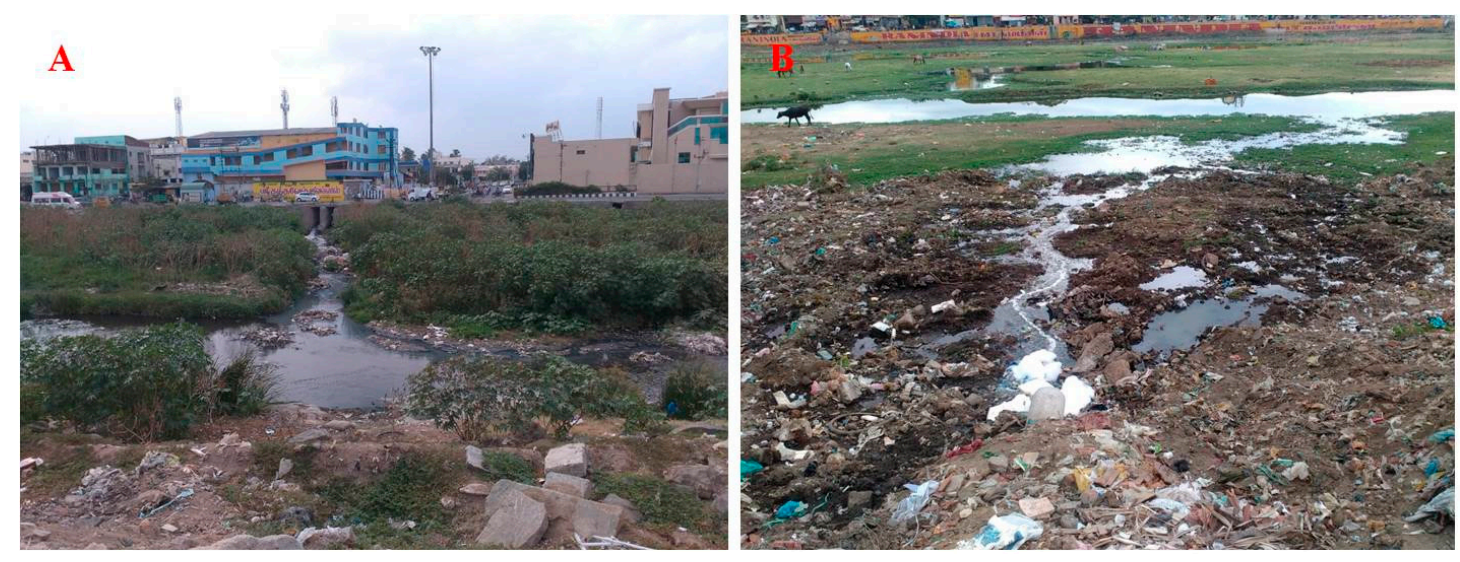

Figure 1. Cont. 

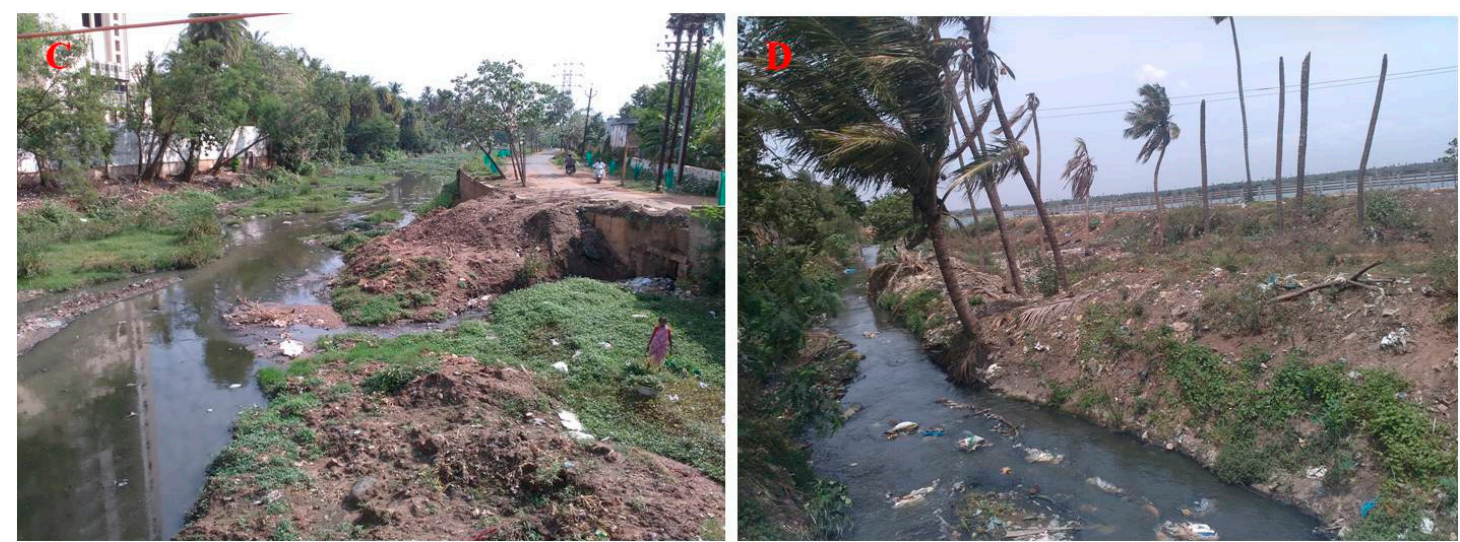

Figure 1. Photos show the direct discharge and impact of untreated urban effluents into the river streams and lake in the south Indian state of Tamil Nadu (A) river Noyyal (Tirupur); (B) river Vaigai (Near the Vaigai Bridge, Madurai city); (C) river Uyyakondan (Trichy); (D) lake Singanallur (Coimbatore). (A-D) photos were taken by Sivalingam in June-July 2017 (dry season).

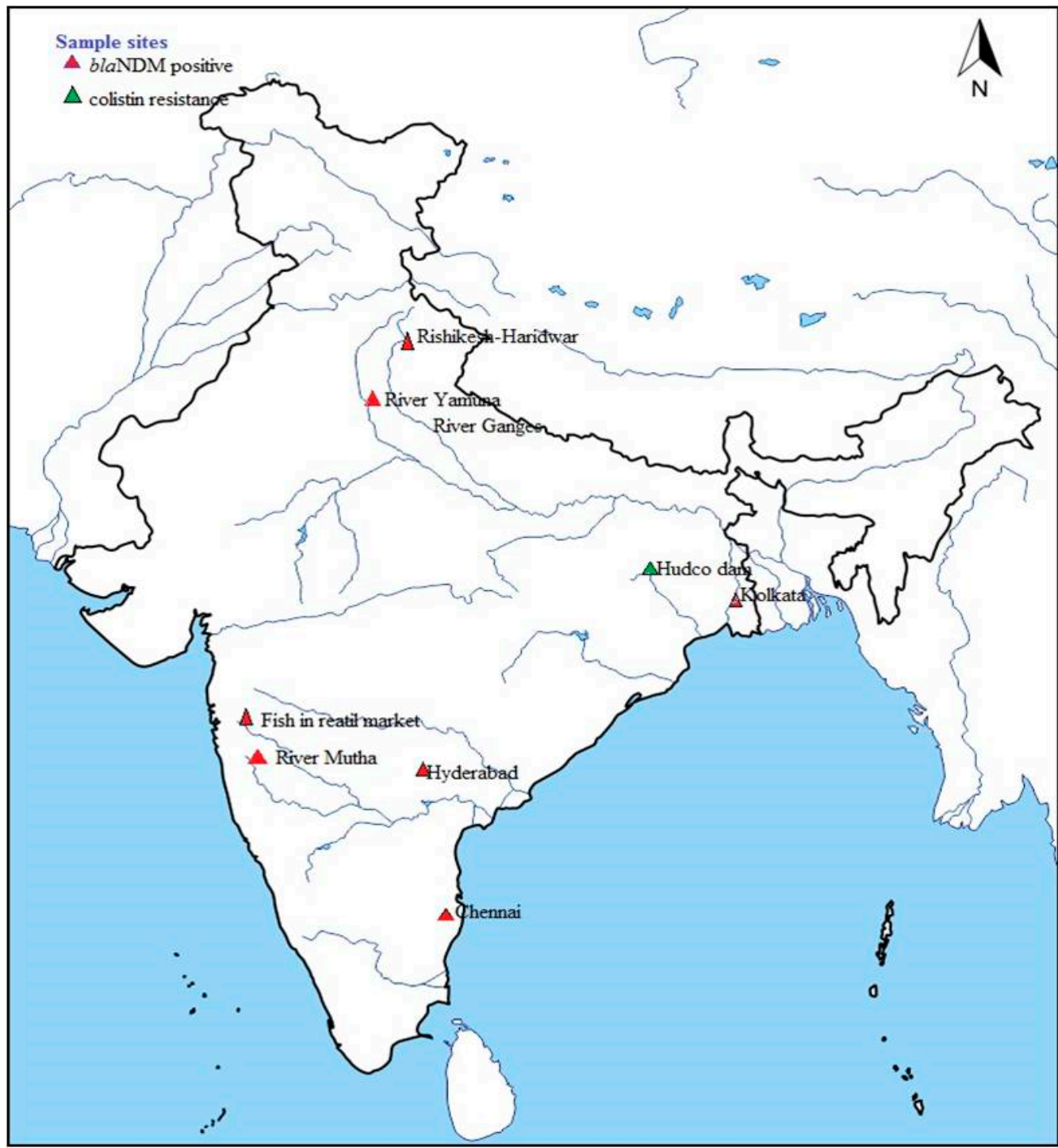

Figure 2. Map showing the geographical location of sampling sites and the occurrence of carbapenemresistant Enterobacteriaceae (CRE). 


\subsection{Central Region}

In hospital effluents from central India, the abundance of E. coli strains and their resistance determinants were investigated. The results showed the coexistence of ARGs, including TEM, CTXM, and OXA 48. Also, one isolate was identified to harbour NDM-1 [97]. The results are in agreement with hospital wastewater which has been proposed as one of the primary environmental sources of CRE [40].

\subsection{Northern Region}

Both drinking water and sewage samples collected from Delhi had been known to contain the $b l a_{\mathrm{NDM}}-1$ gene [96]. The drinking water contamination by $b l a_{\mathrm{NDM}}$ producers can be explained by the fact that water supply pipes are contaminated by public sewer sources during the rainy season. It is also evident that sediment and water samples collected in the Rishikesh-Haridwar region from the upper Ganges pilgrimage sites showed a seasonal presence of NDM genes in waters [98]. The findings suggest that the contamination might be due to a lack of adequate hygiene, unregulated disposal of wastes, discharge of partially treated wastes into upper Ganges region, and bathing during the pilgrimage season [98]. Furthermore, Bajaj et al. (2015) reported the prevalence of E. coli harbouring $b l a_{\mathrm{CTX}-\mathrm{M}-15}$ and $b l a_{\mathrm{CMY}-42}$ in the Yamuna river (India) water samples in the city of Delhi and most of them were resistant to third-generation cephalosporins and cephamycins [77]. The discharge of urban and industrial effluents and agricultural runoff into the river could be a significant source of contamination and the selection of resistant bacteria in the water column.

Remarkably, sewage samples collected from a tertiary care hospital in northern India were found to contain E. coli, Citrobacter freundii, Shigella boydii, Citrobacter braakii, and Citrobacter farmer. All these species were identified to harbour $b l a_{\mathrm{NDM}}$ gene. Besides, $59 \%$ of isolates were found to contain $b a_{\mathrm{CTX}-\mathrm{M}}$ [52]. Moreover, the authors found the coexistence of several resistance determinants in the isolates such as $b l a_{\mathrm{NDM}}, b l a_{\mathrm{CMY}}, b l a_{\mathrm{OXA}}$-type, $b l a_{\mathrm{CTX}-\mathrm{M}}$, and AmpC [52]. Although the source of $b l a_{\mathrm{NDM}}$ producers is not pointed out, the authors proposed that they could have arrived from patient's urine, sputum, and faeces into the effluents. Besides, a single plasmid type is not associated with the $b l a_{\mathrm{NDM}}$ gene, as they found associations with other plasmids, such as IncFIA, IncFIB, IncP, and IncI1, most of the E. coli isolate was found to harbour IncFIA [52], which was corroborated with the previous report [99]. Seasonally collected effluents from the hospital, sewage treatment plants, sewer drains, and water samples from the river Yamuna in New Delhi in 2014 were found to contain CRE with $b l a_{\mathrm{NDM}-1}$. The predominant species were mainly Pseudomonas putida followed by Acinetobacter baumanni and Pseudomonas montelli [4]. However, this is not the case in water samples collected from the Yamuna river, where the dominant species identified were in the decreasing order of Klebsiella pneumonia, Klebsiella pneumoniae subsp. Pneumoniae, and Acinetobacter baumanni [4]. Effluent samples collected from hospitals in New Delhi, 2014, during the winter period were identified to host $b l a_{N D M}$ harbouring Enterobacteriaceae at a higher level than when compared to that found in sewer drains. The most abundant species detected were Klebsiella pnemoniae, E. coli, Acintobacter baumannii, and Pseudomonas putida [100]. Of these studies, NDM was found to be the most common carbapenemase and indicates potential public health threat. Also, this finding suggests systematic monitoring where it has been considered as endemic.

\subsection{Southern Region}

The high abundance of quinolone resistance bacteria in the environmental compartment in India (river) is associated with heavy discharge from antibiotic production facilities and contributes to the spread of ARGs among human pathogens [101]. Very recently, Lubbert et al. 2017 reported the extensive presence of ESBL and CRE harbouring $b l a_{\mathrm{NDM}}$ and $b l a_{\mathrm{KPC}}$ in the environmental samples that were contaminated by antimicrobial drug production industries [102]. It is more obvious that the antibiotic resistance genes and resistant bacteria could have been the selective effect of antibiotics. In another study, Akiba et al. 2016 reported the presence of a high abundance of CTX-M expressing E. coli in the water samples from the river and sewage treatment plant in India [103]. The authors also found that the occurrence of NDM harbouring E. coli. It was further noted that $80 \%$ of the ESBL isolates resistant to 
fluoroquinolones [103]. It seems likely that the identification of various carbapenemase producers may be an indication of rapid spread and evolution in the environment.

\subsection{Western Region}

Recently, Marathe et al. 2017 reported that sediments collected from Mutha river in Pune, India, resulted positive for carbapenem resistance genes such as NDM, KPC, OXA-48, and tet X. Importantly, the authors have also found the presence of colistin resistance gene $m c r-1$ from the upstream sediments, where there is no urban effluents discharge [54]. River sediments collected from the river Mutha in Pune, analysed by next generation sequencing NGS resulted positive for different OXA variations with reduced susceptibility to Carbapenems [15]. It is to be noted that the carbapenemase gene bla $a_{\mathrm{NDM}}$ has also been identified from fish obtained in the retail market in Mumbai, India [104]. Moreover, a recent study has also indicated the occurrence of carbapenemase-harbouring bla $a_{\mathrm{NDM}}$ in the seafood (fish and shellfish) in India. The identified species were Klebsiella pneumoniae and Escherichia coli [105]. The occurrence of carbapenemase-producing Enterobacteriaceae in seafood was probably due to the contamination of urban effluents into surface water and sediments, which might attribute to transfer of ARBs through food web chain. The result is highlighting the need for more studies to explore the transmission possibility of food items and public health relevance.

\subsection{Eastern Region}

Singh et al. 2017 isolated Klebsiella pneumoniae belonging to ST200 and ST1296 from the water samples in Hudco dam, an artificial freshwater reservoir located in Jharkhand, India. The stains were found to be positive for efflux mediated colistin resistance genes [106]. It was probably as a consequence of veterinary use of antibiotics and released into the water harvesting lake, and the selection pressure has contributed to the presence of colistin-resistant Klebsiella pneumoniae in the water column. In a fascinating study, Ghatak and coworkers showed that occurrence of bla $a_{\mathrm{NDM}-5}$ positive Escherichia coli isolated from mastitic milk samples in Kolkata [107]. All these findings substantiate the community-acquired infections reported earlier by Shahid [108].

\section{Future Directions}

\subsection{Infrastructure Development for Sanitation}

Given that India is a developing country, preventive measures will significantly decrease the future spread of ARBs and ARGs in the environment. It is ascertained that the need for better management approaches and the development of appropriate urban infrastructure are on a pilot scale. To effectively control the dissemination into environmental settings, long-lasting underground sewers, waste segregation at the origin and proper disposal, coordinated public health awareness and hygiene, improved sanitation, to emphasize decreasing open defecation, are currently warranted. Towards this end, India has implemented a striking national Swachh Bharat Mission (SBM) that ensures toilets in individual homes and communities across the country.

\subsection{Irrigation Channels Update}

Particular attention should be devoted to pilgrimage and ritual activities in the irrigation channels. In this perspective, illegal dumping of plastics, cloths, solid wastes, and open defecation should be avoided. For example, for an initiative, the river Ganges clean-up project (National Mission for Clean Ganga) is deemed to be of particular interest, and more generally, this could be extended to similar rivers in India. Despite environmental actions to rehabilitate and reduce the sources of the pollutants into the rivers and lakes, their ecological status is still poor.

\subsection{Innovative Changes in Approach in Waste Water Treatment}

Given global warming and climate change, monsoon failure over the year, and more extended periods of droughts started to occur in India. Flooding is also more frequent during a monsoon. 
The rising sewage inflow due to the river drying up during summer, coupled with the decreasing water availability, has affected the river's natural cleaning process. As a result, water availability in most of the rivers and lakes is less constant. In fact, the running waters of most minor rivers and irrigational channels in urban India are primarily composed by the stagnant cesspool of filth, and untreated urban municipal, hospital, and industrial effluents and used for irrigation purposes. Therefore, innovative changes in the approach to wastewater treatment will be crucial.

\subsection{Increased Surveillance of Food Supply Chain}

Since food supply chains constitute a possible route for the spread of ARBs, national authorities should promote policies towards a more efficient way to dispose of landfills, discharge wastewater, urban solid wastes, and hospital wastes on the banks and into the river, streams, and lakes which serve in agriculture. This underscores the urgent need for systematic surveillance studies concerning ARBs and ARGs for green leafy vegetables, ready-to-eat leafy vegetables, seafood, and fish that are in direct contact with contaminated urban effluents, soil, and irrigation water at various stages, such as the harvesting and postharvest level.

\subsection{Antimicrobials Prescription Practices/Accessibilities}

There should be strict national policies implemented to curb the indiscriminate use of antibiotics in aquaculture, agriculture, veterinary, livestock farms, poultry, food animals, and antibiotic stewardship in hospitals. Moreover, it is strongly recommended that there be regulation on the sale of antibiotics at the pharmacy over-the-counter without a prescription. Although the National Action Plan to Combat Antimicrobial Resistance [5] and Chennai declaration, 2013 [109] has led to some development, there is insufficient nationwide surveillance study and effective infection control measures in the environmental compartments.

It will be of great interest to study how the climatic conditions, antibiotic residues, bacterial community, and organic load influence the persistence of CRE in aquatic ecosystems. Moreover, the increase in spending on health care, dedicated actions by different stakeholders, and involvement of non-governmental agencies (NGO) may reduce the spread of CRE and future human health risks. Besides, enhancing the engagement of neighbouring countries in active surveillance of AMR studies, will be largely helpful in tackling antibiotic resistance, and for the implementation of effective control measures.

\section{Conclusions}

The significantly increasing number of literature presented here provides strong evidence for the distribution of CRE in the environment in India. It appears that aquatic ecosystems in India are in worrying conditions, and are identified to have CRE which might pose a severe public health concern. In this context, alarmingly, the resistance determinants identified could be potentially transferred to the microbes present in the environment. Therefore, the further widespread of CRE and evolution of resistance determinants is well foreseeable and could cause severe consequence via exposure pathways to humans. The current situation in India not only requires urgent measures to restrict the further entry of antibiotics and resistant bacteria into the water but also demands research in this area, to understand the mechanisms by which resistant bacteria can persist in the environment.

Author Contributions: P.S. conceived and drafted the manuscript. All authors contributed to the writing and editing of the manuscript.

Funding: This research received no external funding.

Conflicts of Interest: The authors declare that there is no conflict of interests regarding the publication of this paper.

\section{References}

1. O'Neill, J. Tackling Drug-Resistant Infections Globally: Final Report and Recommendations. Review on Antimicrobial Resistance; Wellcome Trust and UK Government: London, UK, 2016; Available online: https://amr-review. org/sites/default/files/160518_Final\%20paper_with\%20cover.pdf (accessed on 1 August 2019). 
2. Gelband, H.; Miller-Petrie, M.; Pant, S.; Gandra, S.; Levinson, J.; Barter, D.; White, A.; Laxminarayan, R.; Ganguly, N.; Kariuki, S. The state of the world's antibiotics. Wound Heal. S. Afr. 2015, 8, 30-34.

3. Public Health Foundation of India. Antibiotic Use and Resistance in India, Global Antibiotic Resistance Partnership-India National Working Group; Public Health Foundation of India: Gurugram, India, 2011; pp. 1-74.

4. Lamba, M.; Gupta, S.; Shukla, R.; Graham, D.W.; Sreekrishnan, T.R.; Ahammad, S.Z. Carbapenem resistance exposures via wastewaters across New Delhi. Environ. Int. 2018, 119, 302-308. [CrossRef]

5. Government of India. National Action Plan on Antimicrobial Resistance (NAP-AMR) 2017-2021. 2017. Available online: http://www.searo.who.int/india/topics/antimicrobial_resistance/nap_amr.pdf (accessed on 1 August 2019).

6. World Health Organization. Antimicrobial Resistance. Global Report; World Health Organization: Geneva, Switzerland, 2018.

7. Col, N.F.; O'Connor, R.W. Estimating worldwide current antibiotic usage: Report of task force 1. Rev. Infect. Dis. 1987, 9, S232-S243. [CrossRef]

8. Batt, A.L.; Snow, D.D.; Aga, D.S. Occurrence of sulphonamide antimicrobials in private water wells in Washington County, Idaho, USA. Chemosphere 2006, 64, 1963-1971. [CrossRef]

9. Andersson, D.I.; Hughes, D. Microbiological effects of sublethal levels of antibiotics. Nat. Rev. Microbiol. 2014, 12, 465-478. [CrossRef]

10. Maiques, E.; Ubeda, C.; Campoy, S.; Salvador, N.; Lasa, I.; Novick, R.P.; Barbe, J.; Penades, J.R. $\beta$-lactam antibiotics induce the SOS response and horizontal transfer of virulence factors in Staphylococcus aureus. J. Bacteriol. 2006, 188, 2726-2729. [CrossRef]

11. Andersson, D.I.; Hughes, D. Evolution of antibiotic resistance at non-lethal drug concentrations. Drug Resist. Updates 2012, 15, 162-172. [CrossRef]

12. Srinivasan, V.; Nam, H.M.; Sawant, A.A.; Headrick, S.I.; Nguyen, L.T.; Oliver, S.P. Distribution of tetracycline and streptomycin resistance genes and class 1 integrons in Enterobacteriaceae isolated from dairy and nondairy farm soils. Microb. Ecol. 2008, 55, 184-193. [CrossRef]

13. Kristiansson, E.; Fick, J.; Janzon, A.; Grabic, R.; Rutgersson, C.; Weijdegård, B.; Söderström, H.; Larsson, G.D.J. Pyrosequencing of antibiotic-contaminated river sediments reveals high levels of resistance and gene transfer elements. PLoS ONE 2011, 6, e17038. [CrossRef]

14. Martínez, J.L. Natural antibiotic resistance and contamination by antibiotic resistance determinants: The two ages in the evolution of resistance to antimicrobials. Front. Microbiol. 2012. [CrossRef]

15. Razavi, M.; Marathe, N.P.; Gillings, M.R.; Flach, C.F.; Kristiansson, E.; Joakim Larsson, D.G. Discovery of the fourth mobile sulphonamide resistance gene. Microbiome 2017, 5, 160. [CrossRef] [PubMed]

16. Marathe, N.P.; Regina, V.R.; Walujkar, S.A.; Charan, S.S.; Moore, E.R.B.; Larsson, D.G.J.; Shouche, Y.S. A treatment plant receiving waste water from multiple bulk drug manufacturers is a reservoir for highly multi-drug resistant integrons bearing bacteria. PLoS ONE 2013, 8, e77310. [CrossRef] [PubMed]

17. Song, J.S.; Jeon, J.H.; Lee, J.H.; Jeong, S.H.; Jeong, B.C.; Kim, S.J.; Lee, J.H.; Lee, S.H. Molecular characterization of TEM-type $\beta$-lactamases identified in cold-seep sediments of Edison Seamount (south of Lihir Island, Papua New Guinea). J. Microbiol. 2005, 43, 172-178. [PubMed]

18. Allen, H.K.; Moe, L.A.; Rodbumrer, J.; Gaarder, A.; Handelsman, J. Functional metagenomics reveals diverse $\beta$-lactamases in a remote Alaskan soil. ISME J. 2009, 3, 243-251. [CrossRef] [PubMed]

19. Aminov, R.I. The role of antibiotics and antibiotic resistance in nature. Environ. Microbiol. 2009, 11, $2970-2988$. [CrossRef]

20. D'Costa, V.M.; King, C.E.; Kalan, L.; Morar, M.; Sung, W.W.L.; Schwarz, C.; Froese, D.; Zazula, G.; Calmels, F.; Debruyne, R.; et al. Antibiotic resistance is ancient. Nature 2011, 477, 457-461. [CrossRef]

21. Allen, H.K.; Donato, J.; Wang, H.H.; Hansen, K.A.C.; Davies, J.; Handelsman, J. Call of the wild: Antibiotic resistance genes in natural environments. Nat. Rev. Microbiol. 2010, 8, 251-259. [CrossRef]

22. Ram, S.; Vajpayee, P.; Shanker, R. Prevalence of multi-antimicrobial-agent resistant, shiga toxin and enterotoxin producing Escherichia coli in surface waters of river Ganga. Environ. Sci. Technol. 2007, 41, 7383-7388. [CrossRef]

23. Knapp, C.W.; McCluskey, S.M.; Singh, B.K.; Campbell, C.D.; Hudson, G.; Graham, D.W. Antibiotic resistance gene abundances correlate with metal and geochemical conditions in archived Scottish soils. PLoS ONE 2011, 6, e27300. [CrossRef]

24. Cesare, A.D.; Ester, M.; Eckert, G.C. Co-selection of antibiotic and heavy metal resistance in freshwater bacteria. J. Limnol. 2016, 75, 59-66. [CrossRef] 
25. Berger, C.N.; Sodha, S.V.; Shaw, R.K.; Griffin, P.M.; Pink, D.; Hand, P.; Frankel, G. Fresh fruit and vegetables as vehicles for the transmission of human pathogens. Environ. Microbiol. 2010, 12, 2385-2397. [CrossRef]

26. Rahube, T.O.; Marti, R.; Scott, A.; Tien, Y.C.; Murray, R.; Sabourin, L.; Zhang, Y.; Duenk, P.; Lapen, D.R.; Topp, E. Impact of fertilizing with raw or anaerobically digested sewage sludge on the abundance of antibiotic resistance coliforms, antibiotic resistance genes, and pathogenic bacteria in soil and on vegetables at harvest. Appl. Environ. Microbiol. 2014, 80, 6898-6907. [CrossRef]

27. Wang, J.; Yao, X.; Luo, J.; Lv LZeng, Z.; Liu, J.H. Emergence of Escherichia coli co-producing NDM-1 and KPC-2 carbapenemases from a retaile vegetable, China. J. Antimicrob. Chemother. 2018, 73, 252-254. [CrossRef]

28. Monier, J.M.; Demanèche, S.; Delmont, T.O.; Mathieu, A.; Vogel, T.M.; Simonet, P. Metagenomics exploration of antibiotic resistance in soil. Curr. Opin. Microbiol. 2011, 14, 229-235. [CrossRef]

29. Donato, J.J.; Moe, L.A.; Converse, B.J.; Smart, K.D.; Berklein, F.C.; McManus, P.S.; Handelsman, J. Metagenomic analysis of apple orchard soil reveals antibiotic resistance genes encoding predicted bifunctional proteins. Appl. Environ. Microbiol. 2010, 76, 4396-4401. [CrossRef]

30. Wright, G.D. The antibiotic resistome. The nexus of chemical and genetic diversity. Nat. Rev. Microbiol. 2007, 5, 175-186. [CrossRef]

31. Jones, J.G.; Gardener, S.; Simon, B.M.; Pickup, R.W. Antibiotic resistant bacteria in Windermere and two remote upland tarns in the English Lake district. J. Appl. Bacteriol. 1986, 60, 443-453. [CrossRef]

32. Pote, J.; Haller, L.; Kottelat, R.; Sastre, V.; Arpagaus, P.; Wildi, W. Persistence and growth of faecal culturable bacterial indicators in water column and sediments of Vidy Bay, Lake Geneva, Switzerland. J. Environ. Sci. 2009, 21, 62-69. [CrossRef]

33. Kwak, Y.K.; Colque, P.; Byfors, S.; Giske, C.G.; Mollby, R.; Kuhn, I. Surveillance of antimicrobial resistance among Escherichia coli in wastewater in Stockholm during 1 year: Does it reflect the resistance trends in the society? Int. J. Antimicrob. Agents 2015, 45, 25-32. [CrossRef]

34. Larsson, D.G.J.; Andremont, A.; Bengtsson-Palme, J.; Brandt, K.K.; de Roda Husman, A.M.; Fagerstedt, P.; Fick, J.; Flach, C.-F.; Gaze, W.H.; Kuroda, M. Critical knowledge gaps and research needs related to the environmental dimensions of antibiotic resistance. Environ. Int. 2018, 117, 132-138. [CrossRef]

35. Baquero, F.; Martínez, J.-L.; Cantón, R. Antibiotics and antibiotic resistance in water environments. Curr. Opin. Biotechnol. 2008, 19, 260-265. [CrossRef]

36. Rizzo, L.; Manaia, C.; Merlin, C.; Schwartz, T.; Dagot, C.; Ploy, M.C.; Michael, I.; Fatta-Kassinos, D. Urban wastewater treatment plants as hotspots for antibiotic resistant bacteria and genes spread into the environment: A review. Sci. Total Environ. 2013, 447, 345-360. [CrossRef]

37. Narciso-da-Rocha, C.; Manaia, C.M. Multidrug resistance phenotypes are widespread over different bacterial taxonomic groups thriving in surface water. Sci. Total Environ. 2016, 563, 1-9. [CrossRef]

38. Picão, R.C.; Cardoso, J.P.; Campana, E.H.; Nicoletti, A.G.; Petrolini, F.V.B.; Assis, D.M.; Juliano, L.; Gales, A.C. The route of antimicrobial resistance from the hospital effluent to the environment: Focus on the occurrence of KPC-producing Aeromonas spp. and Enterobacteriaceae in sewage. Diagn. Microbiol. Infect. Dis. 2013, 76, 80-85. [CrossRef]

39. Cesare, A.D.; Fontaneto, D.; Doppelbauer, J.; Corno, G. Fitness and recovery of bacterial communities and antibiotic resistance genes in urban wastewaters exposed to classical disinfection treatments. Environ. Sci. Technol. 2016, 50, 10153-10161. [CrossRef]

40. Haller, L.; Chen, H.; Ng, C.; Le, T.H.; Koh, T.H.; Barkham, T.; Sobsey, M.; Gin, K.Y. Occurrence and characteristics of extended-spectrum $\beta$-lactamase-and carbapenemase-producing bacteria from hospital effluents in Singapore. Sci. Total Environ. 2018, 615, 1119-1125. [CrossRef]

41. Cesare, A.D.; Eckert, E.M.; Rogora, M.; Corno, G. Rainfall increases the abundance of antibiotic resistance genes within a riverine microbial community. Environ. Pollut. 2017, 226, 473-478. [CrossRef]

42. Rowe, W.P.M.; Baker-Austin, C.; Verner-Jeffreys, D.W.; Ryan, J.J.; Micallef, C.; Maskell, D.J.; Pearce, G.P. Overexpression of antibiotic resistance genes in hospital effluents over time. J. Antimicrob. Chemother. 2017, 72, 1617-1623. [CrossRef]

43. Hrenovic, J.; Ivankovic, T.; Ivekovic, D.; Repec, S.; Stipanicev, D.; Ganjto, M. The fate of carbapenem-resistant bacteria in a wastewater treatment plant. Water Res. 2017, 126, 232-239. [CrossRef]

44. Bengtsson-Palme, J.; Kristiansson, E.; Larsson, D.G.J. Environmental factors influencing the development and spread of antibiotic resistance. FEMS Microbiol. Rev. 2018, 42. [CrossRef] 
45. Piedra-Carrasco, N.; Fabrega, A.; Calero-Caceres, W.; Cornejo-Sanchez, T.; Brown-Jaque, M.; Mir-Cros, A.; Muniesa, M.; Gonzalez-Lopez, J.J. Carbapenemase-producing enterobacteriaceae recovered from a Spanish river ecosystem. PLoS ONE 2017, 12, e0175246. [CrossRef]

46. Poirel, L.; Barbosa-Vasconcelos, A.; Simoes, R.R.; da Costa, P.M.; Liu, W.; Nordmann, P. Environmental KPC-producing Escherichia coli isolates in Portugal. Antimicrob. Agents Chemother. 2012, 56, 1662-1663. [CrossRef]

47. Zurfluh, K.; Hachler, H.; Nuesch-Inderbinen, M.; Stephan, R. Characteristics of extended-spectrum $\beta$-lactamase-and carbapenemase-producing Enterobacteriaceae isolates from rivers and lakes in Switzerland. Appl. Environ. Microbiol. 2013, 79, 3021-3026. [CrossRef]

48. Kittinger, C.; Lipp, M.; Folli, B.; Kirschner, A.; Baumert, R.; Galler, H.; Grisold, A.J.; Luxner, J.; Weissenbacher, M.; Farnleitner, A.H.; et al. Enterobacteriaceae isolated from the river Danube: Antibiotic resistances, with a focus on the presence of ESBL and carbapenemases. PLoS ONE 2016, 11, e0165820. [CrossRef]

49. Di, D.Y.; Jang, J.; Unno, T.; Hur, H.G. Emergence of Klebsiella variicola positive for NDM-9, a variant of New Delhi metallo- $\beta$-lactamase, in an urban river in South Korea. J. Antimicrob. Chemother. 2017, 72, 1063-1067. [CrossRef]

50. Kumarasamy, K.K.; Toleman, M.A.; Walsh, T.R.; Bagaria, J.; Butt, F.; Balakrishnan, R.; Chaudhary, U.; Doumith, M.; Giske, C.G.; Irfan, S.; et al. Emergence of a new antibiotic resistance mechanism in India, Pakistan, and the UK: A molecular, biological, and epidemiological study. Lancet Infect. Dis. 2010, 10, 597-602. [CrossRef]

51. Government of Western Australia, Department of Public Health, Infection Prevention and Control of Carbapenem- resistant Enterobacteriaceae (CRE) in Western Australian Healthcare Facilities. 2012. Available online: http://www.health.wa.gov.au/circularsnew/attachments/712.pdf (accessed on 2 October 2019).

52. Parvez, S.; Khan, A.U. Hospital sewage water: A reservoir for variants of New Delhi metallo- $\beta$-lactamase (NDM)-and extended-spectrum $\beta$-lactamase (ESBL)-producing Enterobacteriaceae. Int. J. Antimicrob. Agents 2018, 51, 82-88. [CrossRef]

53. Khan, A.U.; Nordmann, P. Spread of carbapenemase NDM-1 producers: The situation in India and what may be proposed. Scand. J. Infect. Dis. 2012, 44, 531-535. [CrossRef]

54. Marathe, N.P.; Pal, C.; Gaikwad, S.S.; Jonsson, V.; Kristiansson, E.; Larsson, D.G.J. Untreated urban waste contaminates Indian river sediments with resistance genes to last resort antibiotics. Water Res. 2017, 124, 388-397. [CrossRef]

55. Khan, A.U.; Maryam, L.; Zarrilli, R. Structure, genetics and worldwide spread of New Delhi metallo- $\beta$ lactamase (NDM): A threat to public health. BMC Microbiol. 2017, 17, 101. [CrossRef]

56. Mollenkopf, D.F.; Stull, J.W.; Mathys, D.A.; Bowman, A.S.; Feicht, S.M.; Grooters, S.V.; Daniels, J.B.; Wittum, T.E. Carbapenemase-producing Enterobacteriaceae recovered from the environment of a swine farrow-to-finish operation in the United States. Antimicrob. Agents Chemother. 2017, 61, e01298-16. [CrossRef] [PubMed]

57. Nordmann, P.; Dortet, L.; Poirel, L. Carbapenem resistance in Enterobacteriaceae: Here is the storm! Trends Mol. Med. 2012, 18, 263-272. [CrossRef] [PubMed]

58. Nordmann, P. Carbapenemase-producing Enterobacteriaceae: Overview of a major public health challenge. Med. Et Mal. Infect. 2014, 44, 51-56. [CrossRef] [PubMed]

59. Palzkill, T. Metallo- $\beta$-lactamase structure and function. Ann. N. Y. Acad. Sci. 2013, 1277, 91-104. [CrossRef]

60. Lee, C.R.; Lee, J.H.; Park, K.S.; Kim, Y.B.; Jeong, B.C.; Lee, S.H. Global dissemination of carbapenemase-producing Klebsiella pneumoniae: Epidemiology, genetic context, treatment options, and detection methods. Front. Microbiol. 2016, 7, 895. [CrossRef]

61. Chen, L.; Todd, R.; Kiehlbauch, J.; Walters, M.; Kallen, A. Notes from the field: Pan-resistant New Delhi metallo- $\beta$-lactamase-producing Klebsiella pneumoniae-Washoe County, Nevada, 2016. MMWR Morb. Mortal. Wkly. Rep. 2017, 66, 33. [CrossRef]

62. Yong, D.; Toleman, M.A.; Giske, C.G.; Cho, H.S.; Sundman, K.; Lee, K.; Walsh, T.R. Characterization of a New metallo- $\beta$-lactamase gene, $b l a_{\mathrm{NDM}-1}$, and a novel erythromycin esterase gene carried on a unique genetic structure in Klebsiella pneumoniae sequence type 14 from India. Antimicrob. Agents Chemother. 2009, 53, 5046-5054. [CrossRef]

63. Zarfel, G.; Hoenigl, M.; Würstl, B.; Leitner, E.; Salzer, H.J.; Valentin, T.; Posch, J.; Krause, R.; Grisold, A.J. Emergence of carbapenem-resistant Enterobacteriaceae in Austria, 2001-2010. Clin. Microbiol. Infect. 2011, 17, E5-E8. [CrossRef] 
64. Hornsey, M.; Phee, L.; Wareham, D.W. A novel variant, NDM-5, of the New Delhi metallo- $\beta$-lactamase in a multidrug-resistant Escherichia coli ST648 isolate recovered from a patient in the United Kingdom. Antimicrob. Agents Chemother. 2011, 55, 5952-5954. [CrossRef]

65. Kus, J.V.; Tadros, M.; Simor, A.; Low, D.E.; McGeer, A.J.; Willey, B.M.; Larocque, C.; Pike, K.; Edwards, I.-A.; Dedier, H.; et al. New Delhi metallo- $\beta$-lactamase-1: Local acquisition in Ontario, Canada, and challenges in detection. CMAJ 2011, 183, 1257-1261. [CrossRef]

66. Fu, Y.; Du, X.; Ji, J.; Chen, Y.; Jiang, Y.; Yu, Y. Epidemiological characteristics and genetic structure of $b l a_{\mathrm{NDM}-1}$ in non-baumannii Acinetobacter spp. in China. J. Antimicrob. Chemother. 2012, 67, 2114-2122. [CrossRef] [PubMed]

67. Arpin, C.; Noury, P.; Boraud, D.; Coulange, L.; Manetti, A.; André, C.; M'Zali, F.; Quentin, C. NDM-1-producing Klebsiella pneumoniae resistant to colistin in a French community patient without history of foreign travel. Antimicrob. Agents Chemother. 2012, 56, 3432-3434. [CrossRef] [PubMed]

68. Pasteran, F.; Albornoz, E.; Faccone, D.; Gomez, S.; Valenzuela, C.; Morales, M.; Estrada, P.; Valenzuela, L.; Matheu, J.; Guerriero, L.; et al. Emergence of NDM-1-producing Klebsiella pneumoniae in Guatemala. J. Antimicrob. Chemother. 2012, 67, 1795-1797. [CrossRef] [PubMed]

69. Espinal, P.; Fugazza, G.; López, Y.; Kasma, M.; Lerman, Y.; Malhotra-Kumar, S.; Goossens, H.; Carmeli, Y.; Vila, J. Dissemination of an NDM-2-producing Acinetobacter baumannii clone in an Israeli rehabilitation center. Antimicrob. Agents Chemother. 2011, 55, 5396-5398. [CrossRef]

70. Poirel, L.; Al Maskari, Z.; Al Rashdi, F.; Bernabeu, S.; Nordmann, P. NDM-1-producing Klebsiella pneumoniae isolated in the Sultanate of Oman. J. Antimicrob. Chemother. 2011, 66, 304-306. [CrossRef]

71. Poirel, L.; Revathi, G.; Bernabeu, S.; Nordmann, P. Detection of NDM-1-producing Klebsiella pneumoniae in Kenya. Antimicrob. Agents Chemother. 2011, 55, 934-936. [CrossRef]

72. Jamal, W.; Rotimi, V.O.; Albert, M.J.; Khodakhast, F.; Udo, E.E.; Poirel, L. Emergence of nosocomial New Delhi metallo- $\beta$-lactamase-1 (NDM-1)-producing Klebsiella pneumoniae in patients admitted to a tertiary care hospital in Kuwait. Int. J. Antimicrob. Agents 2012, 39, 183-184. [CrossRef]

73. Brink, A.J.; Coetzee, J.; Clay, C.G.; Sithole, S.; Richards, G.A.; Poirel, L.; Nordmann, P. Emergence of New Delhi metallo- $\beta$-lactamase (NDM-1) and Klebsiella pneumoniae carbapenemase (KPC-2) in South Africa. J. Clin. Microbiol. 2012, 50, 525-527. [CrossRef]

74. Kim, M.-N.; Yong, D.; An, D.; Chung, H.-S.; Woo, J.H.; Lee, K.; Chong, Y. Nosocomial clustering of NDM-1-producing Klebsiella pneumoniae sequence type 340 strains in four patients at a South Korean tertiary care hospital. J. Clin. Microbiol. 2012, 50, 1433-1436. [CrossRef]

75. Jovcic, B.; Lepsanovic, Z.; Suljagic, V.; Rackov, G.; Begovic, J.; Topisirovic, L.; Kojic, M. Emergence of NDM-1 metallo- $\beta$-lactamase in Pseudomonas aeruginosa clinical isolates from Serbia. Antimicrob. Agents Chemother. 2011, 55, 3929-3931. [CrossRef]

76. Rimrang, B.; Chanawong, A.; Lulitanond, A.; Wilailuckana, C.; Charoensri, N.; Sribenjalux, P.; Phumsrikaew, W.; Wonglakorn, L.; Kerdsin, A.; Chetchotisakd, P. Emergence of NDM-1-and IMP-14a-producing Enterobacteriaceae in Thailand. J. Antimicrob. Chemother. 2012, 67, 2626-2630. [CrossRef] [PubMed]

77. Bajaj, P.; Singh, N.S.; Kanaujia, P.K.; Virdi, J.S. Distribution and molecular characterization of genes encoding CTX-M and AmpC $\beta$-lactamases in Escherichia coli isolated from an Indian urban aquatic environment. Sci. Total Environ. 2015, 505, 350-356. [CrossRef] [PubMed]

78. Giani, T.; Pini, B.; Arena, F.; Conte, V.; Bracco, S.; Migliavacca, R.; Pantosti, A.; Pagani, L.; Luzzaro, F.; Rossolini, G.M. Epidemic diffusion of KPC carbapenemase-producing Klebsiella pneumoniae in Italy: Results of the first countrywide survey, 15 May to 30 June 2011. Eurosurveillance 2013, 18, 20489. [PubMed]

79. Chen, L.; Mathema, B.; Pitout, J.D.D.; DeLeo, F.R.; Kreiswirth, B.N. Epidemic Klebsiella pneumoniae ST258 is a hybrid strain. MBio 2014, 5, e01355-14. [CrossRef]

80. Bowers, J.R.; Kitchel, B.; Driebe, E.M.; MacCannell, D.R.; Roe, C.; Lemmer, D.; de Man, T.; Rasheed, J.K.; Engelthaler, D.M.; Keim, P.; et al. Genomic analysis of the emergence and rapid global dissemination of the clonal group 258 Klebsiella pneumoniae pandemic. PLoS ONE 2015, 10, e0133727. [CrossRef]

81. Lascols, C.; Peirano, G.; Hackel, M.; Laupland, K.B.; Pitout, J.D.D. Surveillance and molecular epidemiology of Klebsiella pneumoniae isolates that produce carbapenemases: First report of OXA-48-like enzymes in North America. Antimicrob. Agents Chemother. 2013, 57, 130-136. [CrossRef]

82. Nordmann, P.; Poirel, L. The difficult to control spread of carbapenemase producers among Enterobacteriaceae worldwide. Clin. Microbiol. Infect. 2014, 20, 821-830. [CrossRef] 
83. Pitart, C.; Sole, M.; Roca, L.; Fabrega, A.; Vila, J.; Marco, F. First outbreak of a plasmid-mediated carbapenemhydrolyzing OXA-48 $\beta$-lactamase in Klebsiella pneumoniae in Spain. Antimicrob. Agents Chemother. 2011, 55, 4398-4401. [CrossRef]

84. Seiffert, S.N.; Marschall, J.; Perreten, V.; Carattoli, A.; Furrer, H.; Endimiani, A. Emergence of Klebsiella pneumoniae co-producing NDM-1, OXA-48, CTX-M-15, CMY-16, QnrA and ArmA in Switzerland. Int. J. Antimicrob. Agents 2014, 44, 260-262. [CrossRef]

85. Tafoukt, R.; Touati, A.; Leangapichart, T.; Bakour, S.; Rolain, J.M. Characterization of OXA-48-like-producing Enterobacteriaceae isolated from river water in Algeria. Water Res. 2017, 120, 185-189. [CrossRef]

86. Oliveira, S.; Moura, R.A.; Silva, K.C.; Pavez, M.; McCulloch, J.A.; Dropa, M.; Matté, M.H.; Mamizuka, E.M.; Sato, M.I.; de Castro, A.F.P.; et al. Isolation of KPC-2-producing Klebsiella pneumoniae strains belonging to the high-risk multiresistant clonal complex 11 (ST437 and ST340) in urban rivers. J. Antimicrob. Chemother. 2014, 69, 849-852. [CrossRef] [PubMed]

87. Zurfluh, K.; Nüesch-Inderbinen, M.; Morach, M.; Zihler Berner, A.; Hächler, H.; Stephan, R. Extended-spectrum$\beta$-lactamase-producing Enterobacteriaceae isolated from vegetables imported from the Dominican Republic, India, Thailand, and Vietnam. Appl. Environ. Microbiol. 2015, 81, 3115-3120. [CrossRef] [PubMed]

88. van der Bij, A.K.; Pitout, J.D. The role of international travel in the worldwide spread of multiresistant Enterobacteriaceae. J. Antimicrob. Chemother. 2012, 67, 2090-2100. [CrossRef] [PubMed]

89. Ceccarelli, D.; van Essen-Zandbergen, A.; Veldman, K.T.; Tafro, N.; Haenen, O.; Mevius, D.J. Chromosome-

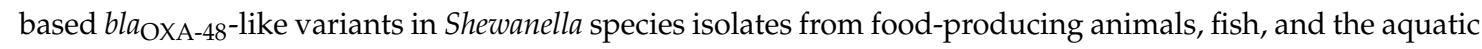
environment. Antimicrob. Agents Chemother. 2017, 61, e01013-16. [CrossRef] [PubMed]

90. Schaefer, M. Water technologies and the environment: Ramping up by scaling down. Technol. Soc. 2008, 30, 415-422. [CrossRef]

91. United Nations (UN). Health, Water and Sanitation; UN: New York, NY, USA, 2011.

92. The Economic Times India has 60.4 per Cent People without Access to Toilet: Study 2015. Available online: https://economictimes.indiatimes.com/article.india/india-news-india/india-has-60-4-per-cent-peoplewithoutaccess-to-toilet-study/ (accessed on 1 August 2019).

93. Ghafur, A.K. An obituary-On the death of antibiotics! J. Assoc. Physician India 2010, 58, 143-144.

94. Laxminarayan, R.; Duse, A.; Wattal, C.; Zaidi, A.K.; Wertheim, H.F.; Sumpradit, N.; Vlieghe, E.; Hara, G.L.; Gould, I.M.; Goossens, H.; et al. Antibiotic resistance-The need for global solutions. Lancet Infect. Dis. 2013, 13, 1057-1098. [CrossRef]

95. Galler, H.; Feierl, G.; Petternel, C.; Reinthaler, F.F.; Haas, D.; Grisold, A.J.; Luxner, J.; Zarfel, G. KPC-2 and OXA-48 carbapenemase-harbouring Enterobacteriaceae detected in an Austrian wastewater treatment plant. Clin. Microbiol. Infect. 2014, 20, O132-O134. [CrossRef]

96. Walsh, T.R.; Weeks, J.; Livermore, D.M.; Toleman, M.A. Dissemination of NDM-1 positive bacteria in the New Delhi environment and its implications for human health: An environmental point prevalence study. Lancet Infect. Dis. 2011, 11, 355-362. [CrossRef]

97. Chandran, S.P.; Diwan, V.; Tamhankar, A.J.; Joseph, B.V.; Rosales-Klintz, S.; Mundayoor, S.; Lundborg, C.S.; Macaden, R. Detection of carbapenem resistance genes and cephalosporin, and quinolone resistance genes along with oq $x A B$ gene in Escherichia coli in hospital wastewater: A matter of concern. J. Appl. Microbiol. 2014, 117, 984-995. [CrossRef]

98. Ahammad, Z.S.; Sreekrishnan, T.R.; Hands, C.L.; Knapp, C.W.; Graham, D.W. Increased waterborne $b l a_{\mathrm{NDM}-1}$ resistance gene abundances associated with seasonal human pilgrimages to the Upper Ganges River. Environ. Sci. Technol. 2014, 48, 3014-3020. [CrossRef]

99. Dortet, L.; Poirel, L.; Anguel, N.; Nordmann, P. New Delhi metallo- $\beta$-lactamase 4-producing Escherichia coli in Cameroon. Emerg. Infect. Dis. 2012, 18, 1540-1542. [CrossRef]

100. Lamba, M.; Graham, D.W.; Ahammad, S.Z. Hospital wastewater releases of carbapenem-resistance pathogens and genes in urban India. Environ. Sci. Technol. 2017, 51, 13906-13912. [CrossRef]

101. Rutgersson, C.; Fick, J.; Marathe, N.; Kristiansson, E.; Janzon, A.; Angelin, M.; Johansson, A.; Shouche, Y.; Flach, C.-F.; Larsson, D.G.J. Fluoroquinolones and $q n r$ genes in sediment, water, soil, and human fecal flora in an environment polluted by manufacturing discharges. Environ. Sci. Technol. 2014, 48, 7825-7832. [CrossRef]

102. Lübbert, C.; Baars, C.; Dayakar, A.; Lippmann, N.; Rodloff, A.C.; Kinzig, M.; Sörgel, F. Environmental pollution with antimicrobial agents from bulk drug manufacturing industries in Hyderabad, South India, is associated with dissemination of extended-spectrum $\beta$-lactamase and carbapenemase-producing pathogens. Infection 2017, 45, 479-491. [CrossRef] 
103. Akiba, M.; Sekizuka, T.; Yamashita, A.; Kuroda, M.; Fujii, Y.; Murata, M.; Lee, K.-I.; Joshua, D.I.; Balakrishna, K.; Bairy, I.; et al. Distribution and relationships of antimicrobial resistance determinants among extendedspectrum-cephalosporin-resistant or carbapenem-resistant Escherichia coli isolates from rivers and sewage treatment plants in India. Antimicrob. Agents Chemother. 2016, 60, 2972-2980. [CrossRef]

104. Singh, A.S.; Lekshmi, M.; Nayak, B.B.; Kumar, S.H. Isolation of Escherichia coli harboring bla $a_{\mathrm{NDM}-5}$ from fresh fish in India. J. Microbiol. Immunol. Infect. 2016, 49, 822-823. [CrossRef]

105. Das, U.N.; Singh, A.S.; Lekshmi, M.; Nayak, B.B.; Kumar, S. Characterization of bla $_{\mathrm{NDM}}$-harboring, multidrugresistant Enterobacteriaceae isolated from seafood. Environ. Sci. Pollut. Res. 2019, 26, 2455-2463. [CrossRef]

106. Singh, S.K.; Mishra, M.; Sahoo, M.; Patole, S.; Mohapatra, H. Efflux mediated colistin resistance in diverse clones of Klebsiella pneumoniae from aquatic environment. Microb. Pathog. 2017, 102, 109-112. [CrossRef]

107. Ghatak, S.; Singha, A.; Sen, A.; Guha, C.; Ahuja, A.; Bhattacharjee, U.; Das, S.; Pradhan, N.R.; Puro, K.; Jana, C.; et al. Detection of New Delhi metallo- $\beta$-lactamase and extended-spectrum $\beta$-lactamase genes in Escherichia coli isolated from mastitic milk samples. Transbound. Emerg. Dis. 2013, 60, 385-389. [CrossRef]

108. Shahid, M.; Malik, A.; Adil, M.; Jahan, N.; Malik, R. Comparison of $\beta$-lactamase genes in clinical and food bacterial isolates in India. J. Infect. Dev. Ctries. 2009, 3, 593-598. [CrossRef]

109. Ghafur, A.; Mathai, D.; Muruganathan, A.; Jayalal, J.A.; Kant, R.; Chaudhary, D.; Prabhash, K.; Abraham, O.C.; Gopalakrishnan, R.; Ramasubramanian, V.; et al. The Chennai Declaration: A roadmap to tackle the challenge of antimicrobial resistance. Indian J. Cancer 2013, 50, 71-73. [CrossRef]

(C) 2019 by the authors. Licensee MDPI, Basel, Switzerland. This article is an open access article distributed under the terms and conditions of the Creative Commons Attribution (CC BY) license (http://creativecommons.org/licenses/by/4.0/). 